\title{
Frontera, narcotráfico y género: las heroínas alternativas de la ficcionalización de la violencia en México/
}

\author{
Border, Drug Traffic and Gender: \\ the Alternative Heroines of Mexican \\ Violence's Fictionalization
}

\author{
Lise Demeyer \\ orcid.org/0000-0001-8360-1538 \\ Université du Littoral Côte d'Opale
}

Violencia y poder son dos conceptos que se suelen atribuir a un ámbito masculino. Sin embargo, cada vez más se elige a una mujer para encarnar al personaje principal de la historia en las obras de ficción mexicanas que remiten a la frontera y al narcotráfico. Partiendo de esta nueva tendencia, el trabajo se basará en tres novelas cuyas similitudes y diferencias en la construcción del personaje principal permitirán señalar nuevas pistas creativas: Diablo Guardián (2003) de Xavier Velasco, Señales que precederán el fin del mundo (2009) de Yuri Herrera y Perra Brava (2010) de Orfa Alarcón.

Palabras Clave: México; Violencia; Frontera; Heroína; Viaje; Género.

Violence and power are two concepts we assign to the masculine field. However, we see that more and more often, a young woman is chosen to play the main character in history in the range of fictional works produced in Mexico. Taking as a starting point this new trend, the work will be based on three novels whose similarities and differences in the construction of the main character will show new creative leads: Diablo Guardián (2003) by Xavier Velasco, Señales que precederán el fin del mundo (2009) by Yuri Herrera y Perra Brava (2010) by Orfa Alarcón.

KEYwORDs: Mexico; Violence; Border; Heroine; Trip; Gender.

Copyright: (C) 2016 CSIC. Este es un artículo de acceso abierto distribuido bajo los términos de una licencia de uso y distribución Creative Commons Attribution (CC-by) España 3.0. 
Eran los protagonistas y nosotras formábamos parte de la decoración. ${ }^{1}$

Se llaman Rosario, Teresa, Violetta, Reina, Makina, Sayra, Sara, Laura o Fernanda. Jóvenes todas que encarnan en la ficción la violencia de un mundo dominado por los varones: el de la frontera y del narcotráfico. No obstante, tanto la inmigración hacia el norte como el tráfico de drogas se atribuyen, en el imaginario común, al ámbito masculino. El narco, el sicario, el coyote, el mojado, el agente de la migra son figuras masculinas que dominan la zona fronteriza en la realidad y en la ficción, tanto literaria como cinematográfica. La mujer es la que se queda en el pueblo, ${ }^{2}$ es la obrera de las maquiladoras, ${ }^{3}$ es la prostituta de los burdeles de las ciudades fronterizas, ${ }^{4}$ es la reina de belleza de los carteles de droga,${ }^{5}$ es la víctima del feminicidio. ${ }^{6}$ En fin, es la que espera y no la que actúa: tiene un papel secundario o, sencillamente, de figuración.

Si establecemos una incompleta pero emblemática cronología de las novelas de la inmigración en México, ${ }^{7}$ en Las aventuras de Don Chipote (1928), ${ }^{8}$ Aventuras de un bracero (1948), ${ }^{9}$ Murieron a mitad del río (1948), ${ }^{10}$ «El paso del norte» (1953), ${ }^{11}$ La frontera plural (1979) ${ }^{12} \mathrm{o}$ incluso en la literatura ultra-contemporánea como Al otro lado (2008), ${ }_{13}^{13}$ etc., el migrante indocumentado es encarnado por un hombre. Su perfil es bastante similar en todos los relatos y no varía mucho a lo largo de los años (casi un siglo de escritura): es un joven trabajador, ingenuo, bondadoso hasta el momento de cruzar el río (si lo consigue), y será víctima de muchos infortunios e injusticias del otro lado de la frontera. Un personaje genérico pues, muchas veces arquetípico, que siempre estará habitado por el sueño de volver a su tierra natal.

1 Alarcón, 2010, 45.

2 Véase, por ejemplo, Las aventuras de Don Chipote de Daniel Venegas.

3 Véase el cuento «Malintzin de las maquilas» de Carlos Fuentes.

4 Podemos pensar en las novelas de Elmer Mendoza, por ejemplo.

5 Véanse, por ejemplo, Santa muerte de Homero Aridjis o la película Miss Bala.

6 Véase Huesos en el desierto de Sergio González Rodríguez o 2666 de Roberto Bolaño.

7 Podríamos abrir esta reflexión a la novela de la migración indocumentada en toda América Latina.

8 Daniel Venegas, 1928.

9 Jesús Topete, 1948.

10 Luis Spota, 1948.

11 Juan Rulfo, 1953.

12 Manuel Álvarez Acosta, 1979.

13 Heriberto Yépez, 2008. 
De la misma forma, la novela llamada del narcotráfico es dominada por los personajes masculinos desde el sicariato colombiano a la narrativa mexicana más actual, pasando por la anglosajona. ${ }^{14}$ Personajes como el jovencísimo Alexis en La virgen de los sicarios (1994) de Fernando Vallejo, o el Zurdo Mendieta, el detective de la saga fronteriza de Elmer Mendoza protagonizan unos relatos en los que la violencia y el poder (casi absoluto), inherentes al narcotráfico, también se vinculan con un universo profundamente machista. Las mujeres son objetos del deseo, elementos constitutivos de los atributos tópicos del capo, tanto como los hipopótamos y tigres de su zoológico particular, las berlinas lujosas o las villas sobreprotegidas. ${ }^{15}$

Sin embargo, en este contexto viril, que se apoya en una semántica real indiscutible, observamos en el elenco de obras de ficción (tanto narrativas como cinematográficas) una nueva tendencia a elegir a una mujer como heroína de relatos en torno a la violencia, la frontera y el narcotráfico.

En el cine más reciente, varias películas son un ejemplo emblemático en este uso de lo femenino en la ficción fronteriza. Tanto el director estadounidense Cary Joji Fukunaga como el hispano-mexicano Diego Quemada-Díez han tratado sobre el tema de «la Bestia», este tren arrollador que lleva a los migrantes de Centroamérica hacia el norte. En Sin Nombre (2009) y La jaula de oro (2013), la juventud de los personajes (unos adolescentes) agudiza el drama actual, el de las maras que genera un nuevo éxodo - precoz y masivo- hacia el norte. Pero la presencia central de una muchacha - Sayra en la primera película, Sara en la segunda - es lo que zanja el peso trágico del viaje: son víctimas del machismo de todos antes de ser víctimas del contexto migratorio. Asimismo, otra película, Miss Bala (2011) de Gerardo Naranjo, trata del tema de la violencia del narcotráfico a través de los ojos de Laura, una reina de belleza captada y manipulada por los sicarios de un cartel. Estas obras cinematográficas actuales participan del nuevo enfoque propuesto por las ficciones ultra-contemporáneas sobre la frontera.

En efecto, prosiguiendo una trayectoria iniciada por las escritoras chicanas como Gloria Anzaldúa, Sandra Cisneros o Estela Portillo Trambley (desde los años 80), por Jorge Franco en Colombia con su famosa Rosario

14 Véanse por ejemplo a las novelas de Don Winslow o Kem Nunn, etc.

15 Véanse Trabajos del Reino de Yuri Herrera y Fiesta en la madriguera de Juan Pablo Villalobos. 
Tijeras $(1999)^{16}$ o por Arturo Pérez Reverte en España con el bestseller La reina del Sur (2002), adaptado luego en telenovela, los nuevos aportes de la actual ficción fronteriza mexicana parecen estribar en el cambio de género del protagonista. Por razones estéticas y éticas que trataremos de resolver a lo largo del artículo, lo femenino (aliado a la juventud) se impone como la nueva forma de retratar un mundo fronterizo caótico y cada vez más al borde del abismo. La heroína, ya no solo como víctima sino también como actriz de la violencia, ha pasado de ser una originalidad a ser una apuesta segura de la ficción actual. Desde luego, permite darles un nuevo enfoque a las injusticias generadas por el monstruo fronterizo, y es lo que vamos a analizar aquí.

En efecto, también en la literatura mexicana de la última década se han multiplicado las novelas protagonizadas por mujeres para retratar la violencia inherente a la frontera. ${ }^{17}$ Este incremento de los sujetos femeninos se puede explicar por el auge de la presencia de escritoras en el mercado editorial mexicano (tanto de la capital como de la periferia). De hecho, las mujeres todavía tienden a elegir a un narrador homodiegético y femenino. ${ }^{18}$ Este punto sería una primera explicación a la proliferación de heroínas fronterizas. Por otra parte, en esta zona que condensa miles de obstáculos y ritos de paso, las aventuras de una mujer acentúan las desigualdades y el nivel de valentía del sujeto.

Para estudiar estas dos líneas explicativas vamos a analizar más particularmente tres novelas distintas por su fecha de publicación (aunque todas del siglo XXI), por su autoría (dos hombres y una mujer) y por su trato del personaje femenino. Elegimos estos tres relatos, sin embargo, porque reúnen una temática común, la frontera (con todo lo que conlleva) y porque sus protagonistas, en los tres casos, presentan una vertiente femenina similar: una fuerza de carácter que les lleva a querer comerse el

16 También en Paraíso Travel (2001) el mismo autor crea el personaje de Reina, una joven que convence a su novio de fugarse de Colombia para ir a Estados Unidos.

17 Pensamos por ejemplo en Después de la montaña (1992), donde Margarita Oropeza cuenta la experiencia de indocumentada de Adelaida Quintero en tierras californianas, en Santitos (2005) de María Amparo Escandón, que propone el viaje de una madre coraje, o en Por el lado salvaje (2011) de Nadia Villafuerte, protagonizada por una adolescente manca.

18 Véase el debate iniciado por Simone de Beauvoir, proseguido por el feminismo francés del post 68 encabezado por Hélène Cixous, y actualizado o refutado por Judith Butler en torno a una escritura calificada de femenina. Sin embargo, aquí, sin entrar en el debate, podemos observar que unos puntos definidos por Cixous y Clément en 1975 para encontrar la feminidad en la escritura son respetados por O. Alarcón: la oralización de la voz (mediante el monólogo interior y el uso del lenguaje coloquial), la relación menos sublimada al cuerpo femenino (aquí veremos una degradación). 
mundo. Contrariamente al patrón aplicado al hombre indocumentado en las novelas de inmigración (tal como lo hemos definido anteriormente), F. Olsson, que ha tratado de sistematizar los contornos del sujeto migrante indocumentado en su tesis, señala «en cuanto a las protagonistas, destaca $[\ldots]$ una tendencia a retratarlas como personajes singulares y extraordinarias - heroínas o villanas-, a diferencia del migrante subalterno arquetípico». ${ }^{19}$ Es esta misma observación lo que ha motivado nuestro trabajo en torno a las tres novelas de nuestro corpus. En efecto, Diablo Guardián (2003) de Xavier Velasco (1964), Señales que precederán el fin del mundo (2009) de Yuri Herrera (1970), y Perra Brava (2010) de Orfa Alarcón (1979), son protagonizadas todas por una mujer impactante (memorable para el lector) y remiten, cada una a su manera, a la migración, al narcotráfico y a la violencia colindante.

Diablo Guardián pone en escena a Violetta, una joven adolescente que se fuga a Nueva York después de haber robado 114.690 dólares en el armario de sus padres, estafadores, estos, de la Cruz Roja. En Señales que precederán el fin del mundo Yuri Herrera reescribe la peregrinación mítica al Mictlán (el «lugar de los muertos» en las culturas mesoamericanas) a través de la persona de Makina, una joven telefonista encargada de llevar un mensaje a su hermano que se fue a Estados Unidos para recuperar el terreno adquirido supuestamente por el padre (también desaparecido en el país vecino). Finalmente, en Perra Brava Orfa Alarcón arrastra literalmente al lector en la vida esperpéntica de Fernanda, la novia de un capo de Monterrey.

Para observar cómo el cambio de género del héroe fronterizo condiciona el mensaje de la obra, empezaremos analizando el proceso de emancipación de las tres protagonistas, Violetta, Makina y Fernanda, desde su subordinación como instrumento de los demás a su afirmación como sujeto soberano. Luego analizaremos, para cada una, su estatus fluctuante de heroína - o anti-heroína - como forma de provocar las certidumbres del lector. Para Makina, el análisis del sujeto se llevará a cabo mediante una lectura doblemente mítica (el Mictlán y la Malinche). En el caso de Violetta, se estudiarán los elementos de la picaresca para definirla como anti-heroína. Y en cuanto a Fernanda, además de una lectura psicoanalítica azuzada por la escritora, se estudiará el viaje constitutivo del personaje a través del patrón del monomito elaborado por J. Campbell.

19 Olsson, 2015, 29. 


\section{Heroínas singulares}

Cada novelista ha creado a tres mujeres que inundan la novela y no dejan ningún sitio para protagonismos secundarios.

Violetta es definitivamente anticonformista, compleja, imprevisible, políticamente incorrecta. También es entrañable. Exaspera al lector porque lleva hasta las últimas consecuencias los sueños extremos (y por lo tanto no realizables) de cada uno de nosotros: despilfarrar el dinero, escaparse, seguir un carpe diem peligroso, no rendir cuentas a nadie. La heroína no tiene límites, no teme ningún vicio. Es venal y materialista: su único motor es el dinero.

Makina es carismática, decidida, sabe defenderse (en contra de los hombres, de los traficantes de droga, de los coyotes y de la policía gringa). Su primer acto de valor es dirigirse a los capos y la focalización interna en su persona revela sus temores interiores, controlados para no revelarlos al mundo exterior. Yuri Herrera propone una comparación hábil entre el terremoto que abre la novela y el pánico de la protagonista: «Sentía la tierra hasta debajo de las uñas como si ella se hubiera ido por el hoyo».$^{20}$ Lo telúrico, lo acuático, atributos femeninos en la dualidad mesoamericana, van a servir para describir las angustias interiores de nuestra heroína a lo largo de la novela. El contraste entre los sentimientos experimentados y el control de su expresión exterior será revelado por el narrador heterodiegético para enseñar que el valor se nutre del miedo.

Fernanda (predestinada por una etimología que apunta a la valentía) es vengativa de un pasado que aborrece. Para salir de la invisibilidad en la que vivió hasta su adolescencia, la heroína se define como una mujer extremadamente decidida. Es también pasional y fiel hasta las últimas consecuencias. Nunca se arrepiente de sus acciones. Fernanda oscila entre momentos de lucidez y fases de locura, una ambigüiedad en la que se sustenta íntegramente la trama de la novela.

Las tres mujeres estudiadas son extraordinarias al luchar contra una normalidad que les parece aburrida o abyecta. Makina, «entendida y leída», ${ }^{21}$ se escapa de su condición (una mujer en un pueblo pobre) por ser autodidacta y dominar los idiomas. Violetta no soporta la hipocresía de su familia católica y de clase media y huye de sus «genes tan corrientes» $»^{22}$ que

20 Herrera, 2009, 13.

21 Ibidem, 87.

22 Velasco, 2003, 194. 
la delatarían como una «naca», ${ }^{23}$ luchando por ser otra, es decir «Libre. Pelirroja. Gringa. Rica. Puta».24 Mientras que Fernanda inicia el proceso inverso al dejar de ser «fresa» ${ }^{25}$ para parecer «naca reguetoneraenseñaombligo». ${ }^{26}$ Hasta esta última le dedica un capítulo a la normalidad que revela su obsesión por ser distinta y reconocida.

\section{La mujer objeto}

Aparentemente, según el trasfondo de estas tres novelas, elegir a una mujer como protagonista implica, todavía en el siglo XXI, tratar del machismo y de la transgresión de su condición en el seno de la trama novelística. El personaje femenino, aquí, no se ha emancipado de las trabas tópicas asociadas a su propio género y, por lo tanto, no es neutral su elección como personaje, como pasa con su equivalente masculino. En las tres obras, en efecto, la heroína plantea los lastres que arrastra su género desde los siglos de dominación masculina. Si Makina lucha desde el inicio para que la respeten los hombres y encarna a la mujer moderna, Violetta y Fernanda son, al principio, víctimas directas de su condición: han asimilado la imagen degradada reservada a la figura femenina en la cultura de masas y en la sociedad. Hablar de mujer-objeto en este contexto (una sociedad regida por las normas masculinas) es hablar de su cuerpo. En efecto, la mente alienada de las protagonistas (en este caso Violetta y Fernanda) abandona al otro el uso de su persona.

Así, de forma in medias res, Orfa Alarcón nos echa en cara el nivel de penetración de la violencia en la sociedad mexicana actual. «Supe que con una mano podría matarme ${ }^{27}$ es la primera frase de la novela y es la forma con la que la joven escritora inicia la descripción de un coito. Estamos ante una colectividad que asume como normal y excitante (se repite este verbo dos veces en el segundo párrafo) la violencia entre los individuos. Mediante la descripción del acto sexual, la novelista consigue revelar las relaciones sociales en el mundo narco: el poder absoluto del hombre se retrata por un sexo brusco mientras que la mujer es cosificada, usada esencialmente

\footnotetext{
23 Ibidem, 273.

24 Ibidem, 80.

25 Alarcón, 2010, 28.

26 Ibidem, 52.

27 Ibidem, 11.
} 
como satisfacción del impulso sexual. El uso de un narrador homodiegético con focalización interna en Fernanda provoca desentrañar la alienación de la heroína: la penetración sexual súbita y agresiva no se vive como una violación sino como un deber, e incluso un premio. La escritora privilegia el monólogo interior para enseñar desde su mundo íntimo las contradicciones de la protagonista. Aquí, desde la primera página, percibimos el síndrome de Estocolmo de la mujer casi esclavizada que profesa un amor incondicional al capo todopoderoso.

Además de ser objeto, también la heroína es animalizada, como lo indica el propio título: Perra brava. Primero será perra, es decir sumisa, antes de ser brava, es decir rebelde. El rebajamiento de la mujer a la única satisfacción del deseo masculino es una aceptación que se explicita por dos motivos en la novela. Primero, como lo indica al final el editor, Orfa Alarcón se inspiró en las letras de varias canciones del grupo de rap Cartel de Santa para imaginar las relaciones entre géneros. Se propone evidenciar una cultura de masas que propaga la misoginia entre los más jóvenes y que la normaliza. El mundo bling bling del hip hop y de los narcos es el reflejo paradigmático de la apariencia, de la presunción del poder y de la representación callejera. Los verbos pronominales como "presumirme», «me exhibiera», ${ }^{28}$ subrayan la instrumentalización de la mujer en el sistema de representación del poder de los carteles.

Segundo, en el caso de Fernanda, el amante idealizado aparece como el único vínculo que la guarda en vida. La sumisión total se sustenta por la ausencia de valor concedida a su existencia: «En contra de ese cabrón no había voz, no había ley, no había voluntad. A los pies de ese cabrón yo había dejado mi vida para que la pateara cuanto quisiera». ${ }^{29}$ Perder fe en la vida y en el futuro genera el abandono del propio cuerpo a otro que lo domine.

Por otra parte, empezamos a conocer a Violetta (así inicia el relato de su propia existencia) con 13 años, edad de la pubertad y del descubrimiento de su anatomía sexuada. Encerrada en su casa porque es castigada constantemente por unos padres que no la aman, el único lugar de transgresión que le queda es el territorio corporal: «emputecí de noche», ${ }^{30}$ «quería poner a prueba mi cuerpo». ${ }^{31}$ Crea un espacio de libertad en su cuarto donde

28 Ibidem, 41.

29 Ibidem, 24.

30 Velasco, 2003, 68.

31 Ibidem, 71. 
puede desarrollar la intimidad evolutiva del adolescente. Poco a poco, alienada mentalmente por su familia (no es una hija sino una esclava ${ }^{32}$ ), su cuerpo se consolida, ya no solo como objeto de rebeldía sino también como recurso para alcanzar sus objetivos: al desnudarse ante un joven vecino generoso empieza a conseguir dinero para financiar sus lujos y escaparse más tarde de su casa. La temprana pérdida del valor concedido al pudor inicia su camino hacia la prostitución. Pronto, el cuerpo es el único vector para llegar a su meta última: la ascensión social.

La desvinculación cuerpo/mente en sus años de prostitución se revela por una pregunta retórica sumamente provocativa a su confesor: «¿Tú crees que si mi vagina no fuera una estúpida, incapaz de pensar en nada, podría soportar las babas de quien sea?». ${ }^{33}$ Contrariamente a Fernanda, la cosificación del cuerpo de Violetta es decisión suya, es un instrumento para sus éxitos (que se revelarán siempre fracasos), su arma, ${ }^{34}$ tiene consciencia de ello. Pero esta elección - aparentemente libre- es obviamente contaminada por la degradación de la figura femenina en las revistas de moda compradas por Violetta, y por las películas porno que descubre en Nueva York (y que aparecen como un instrumento formativo). Su atracción por los «villanos» refleja la asimilación de una supuesta inferioridad de la mujer. Como en Perra Brava, la heroína solo contempla dos caminos antitéticos para el destino femenino (propuestos por la cultura popular y los cuentos infantiles): «Si no podía ser princesa, entonces que viniera un villano a esclavizarme» ${ }^{35}$ Como anti-heroínas, tanto Violetta como Fernanda van a seguir la segunda opción, reductora y humillante.

De manera distinta (políticamente correcta), a lo largo de su viaje en solitario, Makina está alerta ante los posibles abusos sexuales. Es absolutamente consciente de lo que representa: es el objeto deseado de todos los hombres - perversos- que van a cruzar en su camino. Un mínimo roce de rodilla la hace desconfiar, con razón, del hombre sentado a su lado. Estas premoniciones certeras denuncian la normalización del acoso machista en la sociedad mexicana, en particular en la anonimidad del viaje migratorio (véase el destino de las adolescentes en las dos road movies citadas en la introducción), y justifican la elección de una mujer como protagonista de

32 El campo semántico de la esclavitud caracteriza su relación con sus padres. Su fuga será una liberación simbólica de las cadenas de la servidumbre casi feudal.

33 Velasco, 2003, 30.

34 Ibidem, 133.

35 Ibidem, 170. 
una historia que pretende revelar los obstáculos del paso hacia el norte. El gesto violento de Makina, doblándole dolorosamente un dedo al agresor, y la reacción sorprendida del susodicho, asustado, demuestran, por un lado, que los hombres no están acostumbrados a que las mujeres sean lo suficientemente valientes para contestar, y por otro, que la protagonista tiene la estatura de una heroína por salirse de la norma. Transformando la focalización (para que esté interna en la persona de Makina) y luego introduciendo un discurso directo (para que la heroína tenga voz propia en este asunto), Yuri Herrera pretende revelar la dimensión claramente feminista de su heroína moderna con un acto aleccionador contra la impunidad masculina sobre las mujeres.

Luego, del lado estadounidense, cada interlocutor masculino, incluyendo a su propio hermano, prosigue el esquema machista. La reiteración de los avances seductores y lujuriosos (casi estructurales del relato) sirve para subrayar el nivel de arraigo de estas creencias entre los hombres. En las mentes masculinas presentes en la novela se antepone la construcción de la mujer como objeto del deseo, al servicio de los hombres.

\section{La mujer sujeto}

Si la sumisión de la mujer se identifica por su corporeidad en las novelas, su paso de objeto a sujeto se va a ilustrar en las tres novelas por el adueñamiento de la palabra.

Primero, la importancia concedida al lenguaje en Señales que precederán al fin del mundo consolida a la heroína como sujeto: tiene el saber y por lo tanto el poder. Como lo indica la similitud asonante de su nombre, Makina es una Malinche moderna: es «la» lengua y «la» intermediaria como lo fue su avatar Marina en la conquista de México por los españoles. En su trabajo es encargada de una central de teléfonos para toda una comarca: domina la comunicación. Como la traductora de Cortés, también habla tres idiomas (una lengua indígena, el español y el inglés), neutralizados y separados en tres espacios arquetípicos por Yuri Herrera: «contestaba en lengua o lengua latina», «llamaban del gabacho [...] y ella les respondía en la suya nueva». ${ }^{36}$

36 Herrera, 2009, 20. 
Por consiguiente, Yuri Herrera se nutre de la reinvención del mito de la Malinche, siguiendo la trayectoria de una larga tradición literaria en México. Octavio Paz, Carlos Fuentes, Elena Poniatowska, Rosario Castellanos, Elena Garro, Laura Esquivel, Margo Glantz, etc. ${ }^{37}$ también reescribieron o analizaron la historia de la amante de Cortés como mito fundacional de la identidad mexicana (enfocada en el mestizaje) o soporte del primer feminismo mexicano. Considerada como traidora de su pueblo (véase el desenlace de nuestra novela), encarna a la mujer activa, de las pocas representantes de su género en los conflictos bélicos, no solo en México sino en el mundo entero. Yuri Herrera crea un personaje de esta estirpe porque encuentra en la figura de la Malinche la ambigüedad entre un carisma único y un destino decepcionante propio de una heroína trágica.

La sutilidad de Makina se realza en su comprensión más importante de los silencios (como parte integrante del lenguaje), como lo demuestra la anadiplosis que subraya un dominio perfecto del trilingüismo: «Makina hablaba las tres y en las tres sabía callarse». ${ }^{38}$ Siguiendo la comparación con la mujer histórica, la Malinche también es famosa como estratega de la conquista. Aquí, el conflicto en el que Makina va a participar a su pesar es la llamada guerra de los narcos. La palabra «emisaria», ${ }^{39}$ que también suele calificar a la amante de Cortés, subraya la dimensión de sujeto activo de nuestra heroína mediante el dominio del habla (expresión y discreción). Las tensiones entre dos carteles se calman en efecto «al escuchar las palabras transmitidas por Makina (que ella no entendía; aunque sí entendiera)»:40 la paz está en su poder.

Por consiguiente, usa el poder de la palabra (con los artilugios de la ironía) como contrapunto al poder de la fuerza física de los hombres. También la hace diferente de los demás y la dispone al altruismo. En su espera en el hotel de la línea fronteriza, en muy pocas frases, el escritor la describe escribana, profesora, lectora para los demás migrantes. La palabra es su arma (constante obsesiva de las tres novelas de Yuri Herrera publicadas), lo que le permite vencer los distintos obstáculos que tendrá que sobrellevar. Sabrá persuadir, defender, torear e ironizar. Acaba burlándose de un policía estadounidense (encarnación de la serpiente pérfida del mito)

37 Demeyer, 2013.

38 Ibidem, 40.

39 Ibidem, 21.

40 Idem. 


\title{
LISE DEMEYER
}

adoptando para sí misma sus certidumbres tópicas como máxima provocación irreprensible:

\begin{abstract}
Nosotros somos los culpables de esta destrucción, los que no hablamos su lengua ni sabemos estar en silencio. Los que no llegamos en barco, los que ensuciamos de polvo sus portales, los que rompemos sus alambradas. Los que venimos a quitarles el trabajo, los que aspiramos a limpiar su mierda, los que anhelamos trabajar a deshoras. Los que llenamos de olor a comida sus calles tan limpias, los que les trajimos violencia que no conocían, los que transportamos sus remedios, los que merecemos ser amarrados del cuello y de los pies; nosotros, a los que no nos importa morir por ustedes, ¿cómo podía ser de otro modo? Los que quién sabe qué aguardamos. Nosotros los oscuros, los chaparros, los grasientos, los mustios, los obesos, los anémicos. Nosotros, los bárbaros. ${ }^{41}$
\end{abstract}

Esta resistencia rabiosa e impulsiva ante la sumisión y la humillación de los otros detenidos demuestra una vez más su altruismo, como motor de su aprendizaje. Su superioridad, ante los demás indocumentados y el propio representante de la ley, se debe al manejo de todos los recursos retóricos, aquí mediante una antífrasis irónica y en voz propia.

En cuanto a Violetta y Fernanda, ambas voces narrativas de su historia, el uso de un lenguaje extremadamente coloquial y sembrado de insultos e incluso de neologismos consolida su dimensión de anti-heroínas. La jerga utilizada revela la degradación que sendas protagonistas atribuyen a su existencia.

Contrariamente al lenguaje cuidadosamente medido por Yuri Herrera, Xavier Velasco y Orfa Alarcón proponen un flujo imparable y sin censura para representar la urgencia de una conciencia confusa y rebelde. El estilo, llevado a su extremo por ambos novelistas, plantea problemáticas estéticas: ¿El argot parece más impropio en boca de una mujer y el atrevimiento literario es más gozoso? ¿La transgresión es mayor cuando se trata de una mujer porque rompe definitivamente el molde? Aquí, ambos parecen disfrutar de esta libertad de tono usado de punta a punta en su relato. El ganador del premio Alfaguara 2003 reconoce así el vínculo entre estilo y género como propósito literario:

Desde 1982 hablaba y hablaba con las chicas y fui depurando la técnica. Y en 1997 puse un mensaje sensual en una página web. Al principio sólo me contestaban hombres, pero luego las mujeres empezaron a curiosear y hacer preguntas. Así estuve tres

41 Ibidem, 114. 
años hasta que me dije: «Bueno, basta ya de perversiones, ponte a redactar». Y me puse a escribir sobre la mujer. ${ }^{42}$

Por otra parte, en cuanto a la trama de ambas novelas, como lo hemos introducido, la construcción del sujeto pasa por la apropiación de la palabra por las mujeres. Por ejemplo, Fernanda no es el arquetipo de la reina de belleza boba que suele acompañar a los narcos. Es una estudiante de filología de la Universidad de Monterrey. No es por falta de inteligencia que nace la sumisión. El lenguaje va a permitir en su caso subrayar la evolución del personaje: como Makina, también está en transición. La asimilación del lenguaje masculino (incluso misógino) del rap y de los suburbios, aparece directamente en el enunciado: cada vez Fernanda es más violenta en su expresión.

Por otra parte, su monólogo interior utiliza como un leitmotiv las anáforas y las repeticiones que subrayan la progresión de su pensamiento y evidencian el carácter obsesivo de la protagonista. El lector descubre de esta forma sus rasgaduras interiores mediante la voz de su conciencia, que revela lo que consigue no enseñar al mundo exterior: «Esa debía ser la definición de "contenerse": todo mi cuerpo contenía a Fernanda. Mi cuerpo era una olla exprés que no debía dejar salir nada». ${ }^{43}$ Esta cita revela la ventaja del uso del monólogo interior: desmentir la pantomima de la mujer-objeto que Fernanda presenta al mundo.

En el caso de Violetta, en cambio, el lenguaje personal no es de autopersuasión sino de autocrítica sarcástica e incluso cínica. La voz en primera persona, desde una distancia temporal sintética, autoriza la expresión de las dudas mediante un diálogo más bien retórico. En efecto, el flujo (el débito es abrumador) del discurso de la protagonista no corresponde a un monólogo interior simultáneo a la acción, sino que es una confesión ulterior, grabada, que tiene vocación de ser escuchada por Pig (el amante y biógrafo) y servir de base testimonial a una posterior narración. El artefacto no es novedoso, pero modifica las intenciones del sujeto. La violencia de las palabras pasa aquí por el prisma de la perspectiva temporal. Violetta se burla de la joven que fue mediante la multiplicación de adjetivos despectivos que reflejan su falta de preparación («pendeja», «ñoña», «palurda», «bruta», «mamona», etc.). Pero espera, mediante el uso abundante de la metaficción y de preguntas que se dirigen a la aprobación (o desaprobación) de

42 Silió, 2003.

43 Alarcón, 2010, 23. 
Pig, una reacción a lo que afirma. El tuteo interrogativo, con la repetición de las preguntas «iMe entiendes?», «¿O no, Diablo Guardián?», proyecta en el narratario la problemática más universal de la recepción, busca el asentimiento para contrarrestar el juicio ajeno ante la amoralidad. La verdad testimonial, al transgredir el último pudor que tenía es su acto de valentía final. Enrique Serna subraya así que «la recreación del habla funciona como un aparato de rayos $\mathrm{X}$ que muestra las fisuras íntimas de la heroína».${ }^{44}$ En efecto, el interés de la novela estriba exclusivamente en la complejidad de Violetta, y no hay mejor camino que percibir lo extraordinario del sujeto por la expresión directa de su conciencia fluctuante.

Finalmente, cabe notar que la protagonista (y es un punto que la une a Makina) presta un especial interés a los efectos de la lengua. Por un lado, su aprendizaje de un inglés underground es una obsesión identitaria para salir de su condición: una nueva lengua para ser otra. Xavier Velasco consigue evitar el spanglish, prefiriendo la perfección semántica de uno u otro idioma. Por otro lado, lleva a cabo sus engaños con la elaboración de un discurso elegido y adaptado a su víctima. Sabe dañar, pero a su vez es dañada por las palabras de sus padres o de Nefastófoles (el chulo y amante), cuyos insultos son más dolorosos para Violetta que cualquier maltrato físico o sexual: «Una roba y putea y vende coca sin verse en el espejo y decir: Yo soy todo esto. Pero igual se lo había contado a Nefastófeles, y él sí podía decir que su nueva amiguita era ratera, narca, puta». ${ }^{45} \mathrm{La}$ formulación, en voz alta, de en lo que se ha convertido, la consolida como el sujeto viciado que es. La verdad oralizada reduce de repente la distancia entre el cuerpo abandonado a los demás y la conciencia de sí misma como sujeto resistente a la degradación.

\section{Makina o la reactualización del viaje mítico sin regreso}

Yuri Herrera se ocupa del tema de la inmigración en Señales que precederán el fin del mundo adaptando a la problemática fronteriza actual el mito precolombino del viaje - sin regreso - al Mictlán. La referencia es explícita, ya que los nueve capítulos que componen la novela llevan como título las nueve etapas del viaje mítico. Nuestro escritor suele jugar con las

44 Serna, 2003, 66.

45 Velasco, 2003, 279. 
lecturas dobles y los doble sentidos: aquí nunca va a aclarar si se trata del viaje del alma de Makina (después de haber muerto en el terremoto con el que arranca la novela) hacia su aceptación en los infiernos precolombinos, o el viaje migratorio de Makina a Estados Unidos, con sus pruebas de fuego y la recepción de nuevos documentos de identidad al final de la novela, a modo de renacimiento simbólico.

En los mitos, los trabajos suelen ser realizados por un hombre (o por un grupo de mujeres). Yuri Herrera aquí quiere llevar a cabo una reescritura moderna del viaje al Mictlán y la mujer autónoma forma parte de esta renovación. Así justifica esta elección:

Muy pronto me quedó claro que el personaje que debía realizar el viaje era una mujer, por la clase de desafíos y obstáculos extra que tiene que enfrentar una mujer al hacer un viaje en solitario. ${ }^{46}$

De manera que el sexo es el elemento que define la independencia y la fuerza de la protagonista. La aclaración del escritor acerca de la elección de su protagonista también se explicita en el relato y es el punto de partida de las peripecias de Makina por ser mujer. En efecto, según su madre, es la única que puede hacer el recado: «Vaya, lleve este papel a su hermano, no me gusta mandarla, muchacha, pero a quién se lo voy a confiar ia un hombre?». ${ }^{47} \mathrm{El}$ inciso y la interrogativa demuestran el miedo de la espera mítica de Penélope. No puede confiar en los hombres, porque el padre y luego el hijo salieron de México para nunca volver, y sucesivamente abandonaron a su familia. Yuri Herrera revela aquí la miseria del México rural, regida por normas machistas, dependiente de las remesas de los emigrados y subordinada a los servicios (logísticos, financieros) de los narcotraficantes: «los duros» de la novela, a la vez protectores y peligrosos.

Para pasar la serie de obstáculos propios del viaje migratorio y adaptados al viaje al Mictlán, Makina va a usar como arma (además de la lengua) su conciencia de las debilidades de la sociedad machista (véase lo que analizamos en la parte titulada «La mujer objeto»). En contraposición, la seducción nace en el cruce de la frontera entre la heroína y Chucho (un coyote simpático con mote de perro guardián). Esta atracción corporal y emocional es la metáfora de un lento cambio mental en Makina hacia la captación irremediable del Norte-inframundo. Con el enamoramiento

46 Jiménez, 2010, 5.

47 Herrera, 2009, 12. 
repentino, la dimensión del cuerpo femenino evoluciona y el pudor se desvanece: «era cosa no sentir ni miedo ni rabia por encuerarse sin pared de por medio». ${ }^{48}$ Mediante el paso de la frontera geográfica, Makina ha cruzado simbólicamente su propia línea hacia una libertad sexual autorizada por la nueva actitud masculina (que nunca había conocido). Dos negaciones, «sin miedo»y «no comenzara a sentirse culpable», ${ }^{49}$ subrayan el proceso de despojo (metaforizado por el acto de desvestirse), en este caso del yugo impuesto a las mujeres por una sociedad machista y tradicional. La heroína, en este momento de plenitud transitoria, descubre el deseo femenino permitido por el hombre respetuoso y protector. Esta etapa forma parte del viaje iniciático de una mujer. Dudamos que estuviera presente si fuera protagonizado por un hombre.

El mito predestina el fin de la protagonista, ya que Yuri Herrera sigue las mismas pautas que el viaje precolombino. El proceso de captación de Makina va a pasar por la observación, y sobre todo los encuentros que irá haciendo a lo largo de su recorrido. En su pueblo, los que volvieron aparecían como definitivamente desplazados. Al pasar las fronteras, los chicanos son seres en transición, cuya hibridez les diferencia para siempre de su tierra original. Los habitantes de la ciudad estadounidense sustituyen la ilusión del sueño americano por la quimera de una vuelta al país natal:

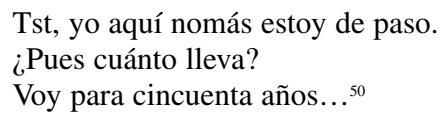

La exageración es irónica, tal como lo es también el juego con doble significado característico de la escritura de Yuri Herrera entre volver al cuartel para el hermano y a México para Makina:

\footnotetext{
Ahí se quedaron, en silencio, hasta que él dijo Tengo que regresar...

Makina asintió. No sabía qué más decir.

¿Tienes con qué volverte?, dijo él, ansioso. ${ }^{51}$
}

Hasta el final el lector confía, a pesar del fatum anunciado por el mito, en la capacidad de deducción de Makina, para que no repita los errores de

\footnotetext{
48 Ibidem, 53.

49 Ibidem, 54.

50 Ibidem, 69

51 Ibidem, 106.
} 
los demás. Su don de comunicación le permite acercarse a las historias ajenas, y más generalmente a la otredad. Su género, además, la diferencia de todas las personas consultadas: ¿Podrá ser distinta? Yuri Herrera no quiere una migrante habitual: le interesa más bien el proceso de adoctrinamiento de un personaje limpio de ilusiones.

Pero el abrazo frío, impersonal, de despedida que se da con su hermano, arrebata emocionalmente todas las enseñanzas absorbidas y sacuden cualquiera de sus certidumbres: «Fue como si le arrancara el corazón, como si se lo extirpara limpiamente y lo pusiera en una bolsa de plástico y lo guardara en el refrigerador para comérselo después $\gg .{ }^{52}$ La modernización del famoso acto ritual mesoamericano (que también corresponde a la séptima etapa del descenso en el inframundo) impulsa a Makina al sacrificio. En la afrenta literaria contra el policía, su defensa sarcástica enseña sin embargo que no solo ha asimilado todos los estereotipos asociados a los migrantes, sino que ella se incluye en esta comunidad subalterna. La repetición del pronombre personal «Nosotros», que inicia y concluye su alegato, transforma definitivamente el viaje temporal en éxodo duradero. La vuelta ya no se contempla porque pertenece, de ahora en adelante, a otra comunidad, la de los migrantes indocumentados.

La última huida, expresada en un campo semántico que subraya la urgencia del movimiento, ya no puede engañar al lector. La liberación de su pesar no se concluirá por una vuelta al país ni por una victoria contra las cadenas de los narcotraficantes. Hasta su fin, hasta en el ambiente surrealista del antro subterráneo, Makina tratará de nombrar las cosas como medio de afirmarse como sujeto humano. El olvido del idioma simboliza la pérdida de identidad, de su ser más profundo, lo que da lugar a una muerte espiritual. Makina está lista para renacer (según el ciclo mítico): le ofrecen falsos papeles para vivir en el inframundo donde, después de haber superado todas las pruebas, es aceptada. La heroína aparece en toda la novela contra cualquier tipo de dominación, bien sea masculina (de los hombres o de los narcos) o neocolonial (Estados Unidos). Pero, por muy extraordinaria que sea, si pensamos fríamente es una mula víctima de los carteles. Y al final se deja influenciar irremediablemente por la voz común, la llamada del Norte. Algunos investigadores han analizado la última palabra, «silencio», ${ }^{53}$ como la muerte de la protagonista, pero podría suponer

52 Ibidem, 107.

53 Ibidem, 123. 
también una página en blanco para recomenzar y aprender a nombrar en el nuevo país. El silencio, lo hemos dicho, es sagrado en la escritura de Yuri Herrera y constitutivo de la singularidad del sujeto.

\section{Violetta, pícara underground de México a Nueva York (ida y vuelta)}

Diablo Guardián aborda una temática (el binomio adolescencia/drogas) ya muy tratada en la ficción, en particular anglosajona. Después de la novela anónima y precursora Pregúntale a Alicia (1971), los años 90 vieron la publicación de la novela generacional Junk (1996) de Melvin Burguess y el estreno de películas emblemáticas tales como Trainspotting (1996) o Requiem for a dream (2000). Además, la literatura del viaje, el road trip y la literatura urbana completan las fuentes de inspiración de Xavier Velasco para crear esta picaresca posmoderna.

La forma misma del relato - la falsa confesión de una Violetta madura- respeta la forma tradicional de la novela picaresca, en la que el antihéroe se arrepiente y propone una lectura moralizante de sus desventuras. En efecto, el relato retrospectivo de Violetta empieza en su pubertad, a los 15 años, y acaba en su edad adulta, a los 25 años, añadiendo algunas analepsis para recordar momentos puntuales y traumatizantes de su niñez. Con reminiscencias del bildungsroman (generalmente encarnado por jóvenes masculinos), la formación de la protagonista se consolida a través de unas desventuras que nos llevan de lo miserable a lo sórdido en un torbellino oral imparable incluso cuando parece tocar fondo. La novela de aprendizaje suele recibir el apego del lector, porque cada uno reconoce una parte de sus dudas formativas en la difícil construcción del personaje. Aquí, las elecciones radicales de Violetta y su propensión a bajar cada vez más los peldaños de la vida digna, provocan un sentimiento ambiguo en el lector. La fase evolutiva, propia del aprendizaje del héroe, va a ser aquí degradada, como lo reivindica Violetta: «Transformar a la niña ñoña en mujer inconveniente». ${ }^{54}$ De hecho, el rock, la cocaína, el shopping, los vídeos porno modernizan el género y son los instrumentos de Violetta para romper en pedazos la moral social y religiosa en la que la criaron.

54 Velasco, 2003, 103 
Como en la picaresca, el punto de partida de las peripecias de la heroína es el rechazo de su condición social, la cual va a querer transgredir inexorablemente. En la reactualización del género narrativo renacentista, Violetta pertenece a una familia conservadora de clase media del D.F. obsesionada por ser otra. El sueño neocolonial que les habita participa del retrato nefasto presentado por el escritor, tanto como explicita el carácter de Violetta. Los padres tiñen a sus hijos de rubio, hablan inglés (incluso en privado), se van de crucero cada año y son devotos. Xavier Velasco expone así el contexto familiar: el malinchismo (definido por Octavio Paz) es la obsesión de esta pareja. Como el pícaro, Violetta es la retoña, en realidad, de padres delincuentes. La cuestión de honor está en el centro del retrato que Xavier Velasco hace de los progenitores. La avaricia les lleva a estafar a la Cruz Roja y a privar de cualquier lujo a sus hijos, hasta regalarle juguetes de segunda mano y ropa usada en Navidad, u obligarles a ducharse con agua fría para ahorrar energía.

El pánico a la normalidad de Violetta inicia una reflexión sobre los complejos de la identidad mestiza (heredada del casticismo colonial). El color de la piel determina a la heroína su lugar en la familia: «mis papás son ovejas mestizas, yo salí negra con modales de cabra». ${ }^{55}$ Violetta, nacida Rosa del Alba, es rechazada, golpeada, ninguneada por unos padres que esperan posicionarse en la sociedad mediante su color de piel. Va a sufrir sobre todo un maltrato mental a lo largo de su niñez: la van a convencer de que no forma parte del núcleo familiar, «Esa muchacha es chiva de otro corral». ${ }^{56} \mathrm{El}$ determinismo del pícaro se plantea también a través de la herencia transmitida por los padres. Con miedo a lo que la recepción deduzca de su relato, Violetta explora de forma reiterada si el mal está presente en sus genes. Sin embargo, la fuerza del personaje es vigente porque Xavier Velasco no cae en la facilidad del substrato psicoanalítico para explicar el malestar de la anti-heroína ni en tópicos maniqueos. Su atracción por el mal aparece como una venganza a su educación católica y a la vez una adhesión reconfortante al dogma cristiano.

Por lo tanto, ante su condición banal, Violetta quiere medrar, ya no cambiar de estamento como el pícaro del Renacimiento, pero lo que es lo mismo, propone una visión clasista y racista de su ambición. Quiere ser rica para dejar de ser «naca». La modificación física pasa por las pelucas y

55 Ibidem, 69.

56 Ibidem, 168. 
el perfeccionamiento de su inglés. Pero no transgrede la forma de actuar de sus padres sino que la repite y la empeora. El paso de la frontera no es motivado por una migración económica sino por los complejos identitarios de cierta mexicanidad. La obsesión por Nueva York ilustra el sueño americano tanto como la elección de las tiendas remiten a una jerarquía capitalista en la cual Violetta quiere llegar a la cima.

La rebeldía desafiante de la protagonista nace para hacer trizas la actitud falsamente comedida de sus padres. El encierro en su cuarto es una primera fase en su aprendizaje: se convence de que el modelo de clase media bienpensante y caritativa es una farsa porque puede observar la otra cara de la representación familiar desde el interior de su casa. Criada en una familia sin amor por haber nacido más oscura de lo que deseaban sus padres, condenada en cambio a no tener amistades en clase «por güerita renegada», ${ }^{57}$ Violetta se acostumbró a la soledad, llenando su mundo interior con la elaboración de un plan para escaparse de una vida aborrecida. Es este mismo modelo de funcionamiento, asimilado en esta fase formativa inicial, el que se va a aplicar en cada uno de sus infortunios.

Cada «plan» para volver a levantarse del abismo en el que ha caído recuerda las astucias (siempre ilegales) usadas por el pícaro, lleno de recursos para tratar de medrar algún día. Ya no es el hambre lo que le empuja a superar cada fracaso sino sus distintas adicciones, a las compras compulsivas primero, a las drogas después, revelando así el materialismo de nuestra época. De la misma manera, los servicios a los amos propuestos por el pícaro original encuentran una nueva significación cuando la novela es protagonizada por una mujer. Electrón libre, el honor de la anti-heroína tiene un precio muy relativo, como afirma irónicamente: «soy una chica llena de virtudes negociables». ${ }^{58}$ En tres frases resume sus contradicciones movidas por la necesidad: pasa de querer ser una «niña rica y decente» (su propia ascensión social), a ser «una niña piruja» (los medios usados para conseguirlo) y resultar «niña idiota» ${ }^{59}$ (el fracaso final). La degradación de los adjetivos retrata a Violetta como una digna heredera de la picaresca.

Sus desventuras se desencadenan en un descenso continuo: desnudarse, robar, fugarse, despilfarrar el dinero, perder su virginidad, estafar, ser escort, probar las drogas, ser drogadicta, prostituirse, vender drogas, mantener a un chulo, ser matona, etc. Como la pícara que encarna, cada nuevo

57 Ibidem, 46.

58 Ibidem, 285.

59 Ibidem, 198. 
plan que elabora fracasa y la lleva a otro. Cada nueva etapa hacia el envilecimiento se avisa irónicamente en el discurso por un amargo «Welcome to the next level», ${ }^{60}$ avisando de la siguiente peripecia. Contrariamente a Fernanda, que no concede ningún valor a la vida, Violetta muestra un empeño por la vida apreciable en las oraciones que lanza en sus peores momentos de cocainómana prostituta: «Ayúdame, Diosito, soy un asco de vieja pero no quiero morirme» ${ }^{61} \mathrm{El}$ final, incierto pero abierto, también respeta las características del género.

En conclusión, Violetta demuestra el sistema feudal vigente en México y en Estados Unidos, donde han nacido nuevas formas de servilismo: el neocolonialismo, el machismo, las exigencias sociales (la apariencia como el antiguo decoro) y la creación de nuevas dependencias (las drogas, el sexo, las compras adictivas). Aunque en ningún momento encontramos una crítica directa por parte de Xavier Velasco, el malestar de Violetta nace, lo hemos dicho, de su condición. Ser mujer, ser mestiza, ser de clase media en México remite a unos complejos de identidad colectiva y nacional. La obsesión por dejar de ser «naca» es una idea común en México, corresponde al temor de siempre ser la «naca» del otro. Aquí Xavier Velasco revoluciona la identidad mexicana de El laberinto de la soledad. La anti-heroína refleja tanto lo subversivo de los años 90 como un complejo identitario (el estado de deshonor del pícaro) mucho más arraigado en un contexto social todavía colonialista.

\section{Fernanda, degradando el viaje iniciático del héroe}

La trama de Perra Brava se sustenta en la evolución mental del personaje desde la subordinación a la radicalización. De allí que, en el caso de Fernanda, la emancipación esperada es doble: asumir su condición de mujer y liberarse de las redes del narcotráfico. Por ello, los doce estadios del viaje iniciático del héroe definidos por Joseph Campbell en el patrón del monomito pueden aplicarse al recorrido interior emprendido por nuestra heroína a lo largo del relato. El respeto de la trama tradicional del viaje del héroe demuestra que Orfa Alarcón quiere presentarnos hasta el último momento a su protagonista como una heroína, para provocar luego en el lector una decepción enorme y un desapego total.

60 Ibidem, 241, 257 y 333.

61 Ibidem, 306. 
Así, podríamos esquematizar lo sucedido en los siguientes puntos:

1. El mundo ordinario: Fernanda es una adolescente que sufre por su invisibilidad.

2. La llamada de la aventura: La manera de alejarse de su vida ordinaria será desear a los hombres malos, encarnados por Julio, su «macho mamón insolente». ${ }^{62}$ Conocerá por primera vez a este brevemente en el baile de fin de curso, en el que es ninguneada por los demás.

3. Reticencia del héroe o rechazo de la llamada: Fernanda pierde de vista a Julio.

4. Encuentro con el mentor: Fernanda se cruza por casualidad con Julio en un aeropuerto. Es un segundo y definitivo flechazo para ella.

5. Cruce del primer umbral: Fernanda se instala en una casa comprada por Julio y penetra para siempre y sin percatarse en el universo narco.

6. Pruebas, aliados y enemigos: Fernanda se da cuenta de que Julio la engaña con otras y forma parte de una organización ilegal porque vuelve cubierto de sangre a casa.

7. Acercamiento: Fernanda acompaña a Julio a una de sus reuniones (entre narcos) y es presentada oficialmente como su pareja.

8. Prueba difícil o traumática: En esta reunión Fernanda, que se siente abandonada por Julio, besa a Mónica, jefa de otro cartel. Julio la golpea en público y la abandona completamente durante semanas. Fernanda está totalmente perdida. Un día recupera su coche dejado delante de su casa por el Coyota, uno de los sicarios contratados por Julio. Es detenida por la policía. En los asientos traseros hay una cabeza cortada. Es inculpada pero no denuncia a Julio ni a su organización, sino que asume la responsabilidad.

9. Recompensa: Gracias a un soborno, Julio la recupera y vuelve con ella declarándole su amor incondicional y pidiéndole la mano. A partir de su sacrificio (inculparse), se invierten los papeles: es ella la que protege a los demás.

10. El camino de vuelta: La vuelta a su rutina es difícil y caótica. Fernanda se va alejando irremediablemente de un Julio cada vez más a sus pies.

11. Resurrección del héroe: Fernanda consigue (mediante las influencias de Julio) una beca para estudiar dos semanas en Japón. Es un pretexto

62 Alarcón, 2010, 21. 
que ella se inventa para quedarse escondida en Monterrey y reflexionar sobre las salidas posibles a su vida en forma de impasse.

12. Regreso con el elixir: La decisión (el elixir) es totalmente radical: la única salida viable es matar al padre para volver a su normalidad. Pero primero, por celos, quiere asesinar a la amante de Julio. Quema su casa pero el que sale muerto es un niño, hijo del capo. Su barbarie ha superado a la de Julio. Cuando este viene a verla, no la mata a ella sino que se suicida ante sus ojos. Al final ha provocado la muerte del padre simbólico, es decir Julio.

Los estadios 1 a 5 se cuentan mediante unas analepsis que reconstruyen la niñez y la adolescencia de Fernanda y que sirven para que entendamos su vida errática. Sufre claramente por una madre ausente y un padre borracho y violento. El enfoque psicoanalítico del que Orfa Alarcón usa (y abusa) para construir su personaje autoriza el análisis de los traumas infantiles y los complejos de Fernanda. La escritora propone un rastreo freudiano de los miedos de la heroína. Su inestabilidad relacional y la concepción sumisa que atribuye a la figura masculina nacen de la precariedad familiar en la que se ha criado y de la violencia machista perpetrada por un padre idealizado. Las imágenes traumáticas («tenía el cadáver de mi madre engarrotado encima» $)^{63}$ la atormentan hasta en sus sueños. La protección, la propiedad y la sangre son los hilos conductores de la novela, porque obsesionan la conciencia de Fernanda al ser distorsiones de sus traumas reprimidos. Además, en toda la novela esta se caracteriza por su soledad y la falta de referencias. Su hermana Sofía (la voz de la sabiduría según la etimología), su sobrina Cynthia, su mejor amigo Dante (que remite al poeta de los infiernos), su novio Julio (encarnación del César moderno) y los Cabrones, los sicarios del cartel (en particular el Chino, del que se va a enamorar) son las únicas personas que comparten su vida. Charlar con los tres primeros es, porque representan la normalidad, la única vía de escape, aunque temporal, a su encierro moral en la jaula narco. Su enloquecimiento se iniciará conforme se vaya alejando de sus tres confidentes. En efecto, la locura se agudizará cuando desaparezca el diálogo en beneficio del exclusivo monólogo interior: Fernanda ya no conseguirá razonar y elegir la vía sana.

63 Ibidem, 26. 
Los estadios 5 a 7 ocupan la primera mitad de la novela, ${ }^{64}$ una etapa en que Fernanda reivindica su estatus de sumisión total al hombre. Efectivamente, pertenecer a alguien y sentirse amparada (aunque de forma relativa) es una forma de redimir sus miedos formativos descritos en los flashback. Así se explicita, en un auto-psicoanálisis en el que deja el campo libre a su conciencia (enseñado a nivel tipográfico por la anulación de cualquier signo de puntuación en 15 líneas) y que es muy aclarador para el lector:

[...] todo eso de haber soñado que la vida podía ser distinta que en la vida se podía amar era ese sueño que tienen los niños porque yo no había sido niña a los seis años desperté y ya era grande y sabía del infierno y de la sangre y cuando abrí los ojos estaba Julio y sus ganas de matar nunca me intimidaron porque yo siempre quise morirme por eso había acomodado mi cuello entre sus dientes. ${ }^{65}$

Julio es claramente el padre de sustitución. Su vida adulta es una recreación del esquema que conoció en su niñez. Estamos ante un complejo de Edipo (o en este caso de Electra, padre-hija): Fernanda vive un amor paternalista con Julio y al final provoca su muerte, es decir, que el magnicidio es simbólicamente un parricidio. Como lo acabamos de demostrar, Orfa Alarcón se nutre del psicoanálisis freudiano para construir a su personaje.

El estadio 8, ${ }^{66}$ como en el monomito de Joseph Campbell, es el núcleo de la novela y marca una ruptura clara en la falsa rutina de Fernanda. Debido a los complejos arriba señalados, aparece como fácilmente manipulable y se revela su punto débil: su necesidad imperiosa de seducir. Es lo que precipita su fin.

En el estadio $9,{ }^{67}$ se enseña claramente que ha vencido al «monstruo»: ha cumplido el rito de aceptación del cartel y ha ganado la confianza de Julio. La recompensa se concluye por una ruptura total en la construcción de su mundo personal y el inicio de una nueva fase para Fernanda. La visión de la cabeza cortada que los policías tiran en sus rodillas funciona como un electrochoque en el viaje iniciático de la heroína: es un nuevo trauma que tendrá que asumir. Tampoco le gusta lo que ha ganado: Julio ya no representa la figura temida que amaba. A partir de esta fase, y hasta el final de la novela, Alarcón juega con una inversión completa de papeles entre la primera y la segunda parte. Su rebelión se avisa por una frase en

64 Ibidem, 11-49.

65 Ibidem, 58.

66 Ibidem, 50-74.

67 Ibidem, 75-85. 
discurso directo dirigida al principal interesado y que se diferencia de su monólogo interior porque la oralidad la hace irremediable: «-No me digas "princesa" $\gg{ }^{68}$ La negación, como representación cognitiva de la emancipación del sujeto, se convierte en la única respuesta que Fernanda dirigirá a Julio en discurso directo durante los estadios 9 y 10 . En esta misma inversión de valores, la dicotomía adentro/afuera que parecía tranquilizarla en la primera parte de la novela aparece de repente como un encierro del que hay que liberarse.

Durante el camino de vuelta, ${ }^{69}$ sus sueños indican una vía hacia la emancipación que pasa por borrar todas las certidumbres cómodas con las que se mantenía en vida en su cotidiano, falsamente ordinario, de la primera parte. Si Julio era digno de amor porque era «dueño y señor», ${ }^{70}$ ahora sus afirmaciones como «nadie tiene a nadie», «solo me tendría a mí misma», invierten completamente su aceptación de la propiedad. Por otra parte, la blandura de Julio hacia ella modifica su imagen (ya no encarna la figura paterna) y colma un deseo que antes parecía inalcanzable y por consiguiente la decepciona: «la desaparición de mi Julio», «(Él no era mío, y cuando comenzó a serlo, dejó de ser Él)». ${ }^{72}$ El paréntesis explicativo y la epanadiplosis que pone en valor el pronombre personal ponen de relieve en el enunciado la caída de Julio de su pedestal de figura masculina única y totalizadora.

Además, cabe notar que Alarcón construye su relato en la repetición de escenas para que el lector, primero empático con Fernanda, pueda advertir su degradación moral. Aquí la cabeza cortada del comandante que la había detenido (sentenciado por orden de Julio), el dolor de la esposa y sus «hijitos», así como la perdida de inocencia de los niños que descubrieron el cadáver conmueven a Fernanda hasta tal punto que tiene una reacción física a la violencia (de asco y vómito), prueba de que el contexto la supera. El estadio 12 contrastará directamente con esta reacción ya que la muerte de un niño (volvemos a la inocencia infantil) que ella misma provoca no llegará a inmutarla. En esta fase del camino de vuelta (10), Fernanda tiene una nueva mirada sobre el mundo y su condición. También le va a pesar la culpabilidad de dos muertes: la del comandante y la del Coyota, ambos

68 Ibidem, 83.

69 Ibidem, 86-123.

70 Ibidem, 11.

71 Ibidem, 85.

72 Ibidem, 118. 
castigados implacablemente por Julio después del incidente de su detención. Al tocarla de cerca, los crímenes de su pareja se hacen reales y ella tiene dos opciones: huir o asimilar la violencia como la única normalidad.

La tentación de omnipotencia («Estaba en la cima del mundo, podría ser coronada reina de belleza» $)^{73}$ conlleva soñar con vengar a su madre y asesinar a su padre. Pero poder y violencia (una pareja que se establece aquí como inextricable) todavía no salen victoriosos en el debate interior de Fernanda. De manera muy hábil, Alarcón superpone un diálogo (discurso directo) entre Julio y Fernanda a reflexiones interiores de esta que revelan el endurecimiento de la heroína y su proceso de distanciamiento y emancipación. La fuerza de la novela estriba en la inestabilidad de Fernanda en esta fase clave. Actúa y piensa de forma bipolar. En efecto, en sus actos alterna entre mimetizarse con los narcos (apariencia, seducción, egoísmo y odio hacia los demás) y soñar románticamente con una vida normal (en Estados Unidos o junto al Chino, un sicario culto y tierno).

El estadio $11^{74}$ corresponde a una etapa de reflexión clave. En un momento de lucidez, Fernanda revela el poder implacable de los carteles, que no contempla una marcha atrás: «Yo era la única pendeja universitaria que no vio nada hasta que estaba metida hasta el cuello». ${ }^{75}$ Aquí el lector, empático como nunca, espera que tome una decisión salvadora y en este punto de la trama todavía es factible (huir a Estados Unidos junto a su hermana y su sobrina). Aun se presenta en la novela como una víctima de los narcos, que representaron una sustitución simbólica a las carencias afectivas de su niñez. El receptor aun la compadece por el enfoque psicoanalítico empleado por Orfa Alarcón para elaborar a su personaje. La repetición de la expresión de probabilidad «podía ser» en el discurso de Fernanda en la primera hora de su fuga es también un artificio de la escritora, en el pacto de lectura, para inducir un alivio en el lector: todavía hay una salida a esta realidad amenazadora. Pero la sed absoluta de seducción y de reconocimiento de la heroína frustra las últimas expectativas del lector. Sus actos transgresivos solo se limitan a copular con varios amantes: va ocupando poco a poco el papel de Julio en la primera etapa. Actúa con el Chino, aprovechando sus sentimientos, para alienarle mentalmente, tal como hacía el capo con ella hasta el estadio 8. La emancipación es entonces una toma de poder representada simbólicamente por una liberación sexual donde se

73 Ibidem, 87.

74 Ibidem, 124-154.

75 Ibidem, 139. 
denota un enfoque feminista. Fernanda toma por fin la iniciativa, como lo indica el uso de la exclusiva primera persona del singular: «por primera vez en mucho tiempo me preocupé por mi propio placer, por metérmelo y frotármelo a mi gusto, por seguir la velocidad que dictara mi deseo». ${ }^{76}$ Fernanda es provocativa, violenta, pero no es capaz de alejarse de su mundo. Su fuga (a Japón) se limita en realidad a encerrarse en un cuarto de hotel con una televisión que la vincula irremediablemente, mediante las noticias morbosas, a su rutina diaria. Poco a poco, se va revelando el desliz de la heroína. La fase de exploración interior desemboca en realidad en una obsesión por asesinar a su padre. Si bien el trato psicoanalítico empleado por la escritora ha revelado que en la figura paterna se encontraba el origen de los traumas de Fernanda, esta aparece aquí como contaminada por una sociedad en la que la violencia es banalizada y estructural. El símbolo freudiano de matar al padre se contempla en sentido propio: la venganza se asimila como único remedio a estados emocionales desagradables como miedo, celos, envidia o humillación.

El estadio 12 se debe observar como una evolución en la construcción del propio sujeto literario: la heroína accede definitivamente al estatus de anti-heroína $\mathrm{y}$, contrariamente al mito del héroe definido por Joseph Campbell, no sale enaltecida sino irremediablemente degradada. El regreso a casa consagra la superioridad de Fernanda sobre Julio; la canibalización de su papel prepara al desenlace funesto, ya que el capo encarnaba la barbarie. Cuando se hace tangible el adulterio de Julio, los celos extremos nacen más de la necesidad de posesión y de la humillación que del amor que ya no profesa al capo. Como cualquier narco, da una paliza a la mujer indefensa y embarazada (detalles que sirven para acentuar la perversión de Fernanda e iniciar el proceso de desapego del lector con la protagonista). La exclamación despiadada « Ojalá la haya matado!» ${ }^{77}$ anuncia el final: la heroína ha pasado definitivamente por el lado del odio y de la venganza. Sin arrepentimiento, cree que va a ser sentenciada por Julio. En cambio, este la protege de las represalias de otro cartel. Esta reacción inesperada del capo la propulsa a otro nivel: lleva la voz cantante y es la que decide. Sin la figura dominante del novio, como lamenta mediante una metáfora canina («pero tú ya no me muerdes») ${ }^{78}$ está totalmente fuera de control. Avisa y premedita su crimen, pero ante la pasividad de Julio que se niega en

76 Ibidem, 135.

77 Ibidem, 163.

78 Ibidem, 179. 
ponerla en los rieles, Fernanda ya no tiene frenos para llevar a cabo su venganza y ser, prosiguiendo la alegoría, «el perro que ladra más fuerte». ${ }^{79} \mathrm{Su}$ miedo traumático por la sangre también condiciona su crimen: no puede verla, así que tendrá que quemar para matar, un asesinato cobarde y que resultará equivocado ya que matará al hijo y no a la amante. Su frialdad radical (incluso su «euforia» ${ }^{80}$ distorsiona el propósito del monólogo interior: asesinar a una criatura pone a prueba los límites de la empatía de lector (encarnado aquí por el desapego de Dante) para con el personaje. Matar al símbolo de la inocencia y no sentirse arrepentida desprestigia definitivamente a la figura de la protagonista.

Orfa Alarcón eligió al acto más imperdonable para provocar un rechazo inequívoco. También deconstruye la imagen de pureza (la virgen) o de histeria (la bruja) reservada a las mujeres de ficción: Fernanda es capaz de matar fríamente y de llegar al cinismo, al igual que cualquier hombre. Lo abyecto no tiene sexo, es una construcción mental errática. La afirmación de ella misma, mediante la repetición de «yo» para iniciar cada frase del último párrafo de la novela, petrifica al lector. El desenlace de la tragedia es invertido: como Yocasta (la madre de Edipo) se suicida el capo, vencido por la omnipotencia de una bestia salvaje, esa perra brava del título. Fernanda bebe la sangre del sacrificado, convertida en emperatriz de un mundo masculino que ha doblegado al superar su violencia.

En resumen, Orfa Alarcón utiliza el psicoanálisis para circunscribir las acciones y decisiones de su heroína, entender sus fallos, buscar de dónde nace la violencia. Habíamos hablado de un componente social en la primera parte de nuestro trabajo, pero también observamos los motivos psíquicos. Alarcón plantea de la siguiente manera los cuestionamientos que hemos mencionado: ¿existe una justificación de la violencia?, ¿hay excusas a la barbarie? El trasfondo socio-psicológico usado por la escritora, así como el uso del patrón del viaje iniciático del héroe, relata cómo una chica normal cruza el umbral de la ilegalidad e ingresa al mundo narco. No obstante, el papel reservado a la mujer en la sociedad y la cultura de masas (televisión, rap y reguetón) así como los traumas infantiles de Fernanda en ningún caso justifican el horror vengativo y enloquecido del final de la novela. Fernanda, al seguir las distintas etapas que llevan hasta el desenlace trágico, tuvo posibilidad de salvación mediante unas puertas dejadas

79 Ibidem, 188.

80 Ibidem, 198. 
abiertas por la escritora: Sofía, Dante, el viaje a Japón, el Chino eran posibles escapatorias que la anti-heroína rechazó. No es un personaje trágico cuyo fatum se encontraba preescrito (aquí el complejo de Edipo es freudiano y no mítico). Orfa Alarcón levanta pistas para entender la dualidad del personaje, pero induce a pensar que son sus elecciones, erróneas, las que le llevan a sumirse a la barbarie del mundo de los narcos.

Para concluir, las tres novelas empiezan por la idea simbólica de la muerte: Violetta habla desde la supuesta ultratumba, Makina muere simbólicamente en un terremoto premonitorio que anuncia su marcha hacia el inframundo, Fernanda somete su vida al albedrío de Julio. De hecho, la vida de estas tres mujeres está condicionada por la violencia endémica en México. Pero en las tres novelas esta violencia es distinta. Perra Brava se adentra en la violencia actual de la guerra de los carteles, que no excluye a jóvenes ni a mujeres. El ambiente ominoso que reina en Monterrey se retrata en la novela mediante la cotidianeidad de las escenas familiares: «la ciudad desayunaba teniendo enfrente huevos estrellados, salsa cátsup y unas cavidades vacías de ojos mirándola fijamente» ${ }^{81} \mathrm{La}$ escritora denuncia un hábito ante la violencia mediante la multiplicación de los actos bárbaros y su difusión banalizada (espectáculo) por los medios de masas. La corrupción policial y política se señala claramente como partícipes de esta violencia e indican que no hay ni justicia ni salvación. Señales que precederán el fin del mundo, por su parte, contempla una violencia económica y social (causa y consecuencia de la migración) más oculta pero igualmente actual. Finalmente, Diablo Guardián presenta de forma soterrada la violencia colectiva e íntima de la identidad mexicana, en particular del mestizaje, herencia traumática del sistema clasista y racista colonial. Por consiguiente, estamos ante una violencia social, que excluye por el color de la piel (malinchismo), por el sexo (machismo), por la pobreza (migración) o por no pertenecer al cartel (narcotráfico).

Por otra parte, si la heroína de Alarcón cae de lado del mal cruzando las últimas barreras de lucidez razonable en su mente, nunca llega a pasar del otro lado de la frontera geográfica («ir al gabacho» era la única opción viable para salvarse definitivamente de la enredadera narco), mientras que Violetta y Makina desarrollan su existencia ficcional en el norte de la valla. Como subraya Fredrik Olsson, también nosotros observamos una «falta de mujeres novelistas que se centren en el tema de la migración

81 Ibidem, 86. 
indocumentada». ${ }^{82}$ Se podría justificar por la tentación de quedarse en la madre tierra, y sobre todo por la voluntad de enseñar que no es el cambio de país lo que determina la evolución mental y moral del sujeto. Aquí la violencia omnipresente -individual y colectiva - contamina, lo hemos dicho, las últimas certidumbres de Fernanda. Alarcón apunta que la odisea no tiene por qué pasar por este viaje migratorio: construye un viaje interior que nos lleva hacia las más íntimas contradicciones de la antiheroína, o hacia el mal absoluto.

Si en la introducción señalamos la valentía de las protagonistas como justificación de su género, podemos matizar esta afirmación y decir que es su capacidad de transgresión la que justifica la elección de una mujer para encarnar la historia. Además, en estas tres novelas los personajes femeninos viven en un mundo regido por reglas masculinas. A primera vista el poder y la violencia son atributos de los hombres. Pero pronto cada heroína llega a sobrepasar lo establecido. Como temática común vemos que cada heroína pretende superar al hombre, dejarlo de lado, vencerlo.

Por lo tanto, su singularidad les permite ir más allá de los tópicos que encierra a menudo su género. Reactualizan el mito (Makina), revolucionan un género narrativo (Violetta) o degradan un patrón literario (Fernanda). Son dignas de ser heroínas por su cualidad fronteriza. Makina, intermediaria de palabras, recados y mundos; Violetta, passenger de una sociedad underground a la Iggy Pop; Fernanda nadando a contra-corriente del viaje iniciático, encarnan la frontera por su carácter maleable, fluctuante e imprevisible.

\section{Bibliografía}

Alarcón, Orfa, Perra Brava, Planeta, México, 2010.

Álvarez Acosta, Manuel, La frontera plural, México, Joaquín Mortiz, 1979.

Anzaldúa, Gloria, Borderlands = La frontera, San Francisco, Aunt Lute Books, 1999.

Aridjis, Homero, Santa muerte, México, Alfaguara, 2003.

Beauvoir, Simone de, Le deuxième sexe, Paris, Gallimard, 1986 [1949].

82 Olsson, 2015, 29. 
Bolaño, Roberto, 2666, Barcelona, Anagrama, 2006.

Butler, Judith, El género en disputa: El feminismo y la subversión de la identidad, Barcelona, Paidós, 2007 [1990].

Campbell, Joseph, El héroe de las mil caras, Madrid, FCE, 1992 [1949].

Cisneros, Sandra, Women hollering creek, San Antonio, Random House, 1991.

Cixous, Hélène y Clement, Catherine, La jeune née, Paris, Union Générale d'Editions, 1975.

Demeyer, Lise, «Marina, Malinalli, Malintzin, Malinche. La réécriture du mythe de la Malinche dans la littérature féminine mexicaine contemporaine», en Palma, Milagros (coord.), Amérique latine: le monde amérindien et métis contemporain, Paris, Indigo, 2013, 31-42.

Escandón, María Amparo, Santitos, Barcelona, Plaza\&Janés, 1999.

Franco, Jorge, Paraíso Travel, Bogotá, Seix Barral, 2001.

- Rosario Tijeras, Barcelona, Mondadori, 2006 [1999].

Fuentes, Carlos, «Malintzin de las maquilas», en La frontera de cristal, México, Punto de Lectura, 2007 [1995], 121-150.

Fukunaga, Cary Joji (dir.), Sin Nombre [Película], Estados Unidos-México, 2009.

Herrera, Yuri, Señales que precederán el fin del mundo, Cáceres, Periférica, 2009.

- Trabajos del reino, Cáceres, Periférica, 2009 [2004].

González Rodríguez, Sergio, Huesos en el desierto, Anagrama, Barcelona 2002.

Jiménez, Arturo, «Herrera da vigencia al relato del descenso al Mictlán "desde nuevas coordenadas"» [Entrevista a Yuri Herrera], La jornada, México, 3 de enero de 2010.

Mendoza, Elmer, Balas de plata, Barcelona, Tusquets, 2008.

Naranjo, Gerardo (dir.), Miss Bala [película], México, 2011.

Nunn, Kem, Tijuana Straits, Paris, Sonatine, 2011.

Olsson, Frederik, Me voy pal Norte. La configuración del sujeto migrante indocumentado en ocho novelas hispanoamericanas actuales (1992-2009), Tesis doctoral, Universidad de Sevilla y Göteborgs Universitet, 2015 [en prensa].

Oropeza, Margarita, Después de la montaña, Hermosillo, Instituto Sonorense de Cultura y Gobierno, 1992.

Pérez Reverte, Arturo, La reina del sur, Madrid, Alfaguara, 2002.

Portillo Trambley, Estela, Trini, El Paso, The Feminist Press, 2005 [1986].

Quemada-Díez, Diego (dir.), La jaula de oro [película], México, 2013.

Rulfo, Juan, «El Paso del Norte», en El llano en llamas, Madrid, Cátedra, 2006 [1953], 126-132.

Serna, Enrique, «La Coatlicue de Saks», Letras Libres, México, junio de 2003, 66-67.

Silió, Elisa, «Xavier Velasco revela su historia de amor con Violetta» [Entrevista a Xavier Velasco], El País, Madrid, 26 de abril de 2003 [en línea], http://elpais.com/diario/2003/04/26/madrid/1051356279_850215.html [consultado el 22/02/2016]. 


\section{LISE DEMEYER}

Spota, Luis, Murieron a mitad del río, México, Costa-Amic, 1979 [1948].

Stistrup Jensen, Merete, «La notion de nature dans les théories de 1'“écriture féminine"», Clio, Femmes, Genre, Histoire, 11, 2000 [en línea], http://clio. revues.org/218 [consultado el 15/02/2016].

Topete, Jesús, Aventuras de un bracero, México, Gráfica Moderna, 1961 [1948].

Vallejo, Fernando, La virgen de los sicarios, Bogotá, Alfaguara, 1998 [1994].

Velasco, Xavier, Diablo Guardián, Alfaguara, 2003.

Venegas, Daniel, Las aventuras de Don Chipote o cuando los pericos mamen, Houston, Arte Público Press, 1999 [1928].

Villalobos, Juan Pablo, Fiesta en la madriguera, Barcelona, Anagrama, 2010.

Villafuerte, Nadie, Por el lado salvaje, México, Ediciones B, 2011.

Winslow, Don, El poder del perro, Barcelona, Mondadori, 2009.

Yépez, Heriberto, Al otro lado, México, Planeta, 2008. 